\title{
AL-QUR'AN DAN EKARISTI SEBAGAI PUSAT HIDUP BERIMAN DAN KEROHANIAN UMAT MUSLIM DAN KRISTIANI
}

\author{
Stepanus Sigit Pranoto
}

\begin{abstract}
:
This article is an attempt to explore and practice of comparative theology. Comparative theology itself is unique in terms of its sources and methods, in which theological reflection is built on the basis of a comparison of more than one religious traditions. Moreover, comparative theology emphasizes practice rather than theory. According to the author, comparative theology is a contextual theology that can be developed in Indonesia as pluralistic society. In this practice, the author chooses the Qur'an and the Eucharist as the starting point of the discussion.
\end{abstract}

\section{Kata-kata Kunci:}

Teologi komparatif, Al-Qur'an, Ekaristi, mushaf, realis praesentia, transubstantiatio, sakramen, pluralitas.

\section{PENDAHULUAN}

Di tengah pluralitas agama dan kepercayaan dibutuhkan sebuah sikap keterbukaan di antara pemeluk agamaagama dan kepercayaan. Pantas disyukuri bahwa melalui Konsili Vatikan II (19621965) Gereja semakin menunjukkan keterbukaannya akan adanya realitas pluralitas iman tersebut. Gereja menyadari bahwa rencana keselamatan Allah itu tidak hanya dikhususkan bagi umat Katolik saja. Hal ini secara tegas dinyatakan dalam Lumen Gentium [LG] 16: “....Namun rencana keselamatan juga merang-kum mereka, yang mengakui Sang Pencipta; di antara mereka terdapat terutama kaum Muslimin, yang menyatakan, bahwa mereka berpegang pada iman Abraham, dan bersama kita bersujud menyembah Allah yang tunggal dan maharahim, yang akan menghakimi manusia pada hari kiamat."

Dalam hubungan dengan agama-agama lain, Gereja Katolik juga mendorong umatnya "supaya dengan bijaksana dan penuh kasih, melalui dialog dan kerjasama dengan para penganut agama-agama lain, sambil memberi kesaksian tentang iman serta perihidup kristiani, mengakui, memelihara dan mengembangkan harta-kekayaan rohani dan moral serta nilai-nilai sosiobudaya, yang terdapat pada mereka" (Nostra Aetate [NA] 2). Keterbukaan Gereja akan realitas pluralitas iman ini mengubah cara pandang yang baru terhadap agamaagama lain, di mana mereka juga "memantulkan sinar Kebenaran, yang menerangi semua orang" (NA 2). 
Berkaitan dengan semangat keterbukaan itu, diperlukan pula sebuah metode teologi yang kontekstual. Menurut penulis, teologi komparatif yang akhir-akhir ini berkembang merupakan metode teologi yang mampu menjawab kebutuhan tersebut. Teologi komparatif merupakan sebuah pendekatan baru dalam teologi terhadap adanya plu-ralitas iman. Dalam hal ini teologi komparatif merupakan sebuah teologi kontekstual yang mampu menjawab situasi masyarakat Indo-nesia yang ditandai oleh adanya pluralitas agama.

Dalam semangat keterbukaan dan upaya memperdalam teologi komparatif itulah, penulis hendak melihat salah satu tema penting dalam hubungan antara Islam dan Katolik. Secara khusus penulis akan melihat bagaimana peran penting Al-Qur'an bagi umat Muslim dengan melihatnya dalam perbandingan dengan Ekaristi bagi umat Katolik. Terhadap kedua hal ini, George Dardess membuat pernyataan menarik:

Untuk memperoleh gagasan tentang status Al-Qur'an dalam diri umat Muslim Bayangkanlah membuka pintu tabernakel di dalam gereja Anda dan temukan Kitab Suci di dalamnya sebagai ganti sibori dengan hosti yang sudah dikonsekrasikan. Bagaimana Anda akan bereaksi atas penggantian ini? ${ }^{1}$

Kutipan dari tersebut kiranya bisa memberikan satu gambaran bagaimana peran keduanya bagi masing-masing agama. Bagi umat Muslim, Al-Qur'an merupakan wahyu tertinggi, yang merupakan suara kebijaksanaan Ilahi. Namun karena keterbatasan manusia, kita tak dapat mendengar suara itu secara langsung. Maka dari itu Allah memilih dua instrumen dunia yang memungkinkan suara-Nya dapat kita dengarkan dan kita pahami. Instrumen yang dipilih Allah itu disucikan dan diangkat ke dalam taraf luar biasa. Kedua instrumen dunia yang ditransformasikan itu adalah bahasa Arab sebagai bahasa yang dipakai untuk berkomunikasi dan Muhammad sebagai yang memperdengarkan. Oleh kedua instrumen yang dipilih tersebut, suara Allah hingga kini masih tetap dapat diperdengar- kan kepada umat manusia, yakni dalam teks Al-Qur'an.

Thomas Michel menggarisbawahi bahwa Al-Qur'an juga merupakan pusat dari spiritualitas umat Muslim. ${ }^{2}$ Umat Muslim percaya bahwa Al-Qur'an merupakan Sabda Allah. Maka bagi umat Muslim, perjumpaan mereka dengan Al-Qur'an menjadi perjumpaan mereka dengan Allah yang mewahyukan, mengajar, dan membentuk umat beriman dalam kesucian. Oleh sebab itu, ketika seseorang membaca, mendaraskan, mendengarkan, mempelajari atau pun merefleksi-kan Al-Qur'an, mereka juga mengalami Allah sendiri yang berjumpa dan berbicara dengan mereka.

Peran sentral Al-Qur'an bagi umat Muslim tersebut mengingatkan penulis pada makna dan peran penting Ekaristi bagi umat Kristiani. Bagi Gereja, Ekaristi merupakan sumber dan puncak hidup seluruh umat kristiani (LG 11). Maka sebagai sumber dan puncak hidup Kristiani, Ekaristi juga mendapatkan peran sentral dalam kehidupan umat Kristiani. Hal inilah yang mendorong penulis untuk melihat hubungan Al-Qur'an dan Ekaristi dalam penelitian teologi komparatif ini.

\section{TEOLOGI KOMPARATIF SEBAGAI TEOLOGI KONTEKSTUAL}

Sebelum melihat perbandingan antara Al-Qur'an dan Ekaristi, terlebih dahulu penulis akan membahas tentang apa itu teologi komparatif. Teologi komparatif sendiri merupakan salah satu model teologi yang berupaya untuk menjawab kebutuhan akan adanya metode teologi di tengah pluralitas iman. Dalam konteks pluralitas iman inilah, teologi komparatif ini cocok untuk menjawab kebutuhan tersebut. ${ }^{3}$ Teologi komparatif ini berkembang di kalangan para teolog Roma Katolik, antara lain F. X. Clooney SJ dan James L. Fredericks. Mereka adalah para komparativis yang berpengalaman dalam menekuni ajaran-ajaran dan bertemu dengan berbagai umat beragama lain.

Menurut penulis, teologi komparatif ini menjadi model teologi yang kontekstual berhadapan dengan realita keberagaman agama dan kepercayaan di Indonesia. 
Secara singkat teologi komparatif bisa diartikan sebagai berteologi dalam konteks keberaga-man iman "dengan menjaga ketegangan" (keeping the tension) antara kesetiaan terhadap iman kristiani yang kreatif dan keterbukaan terhadap kebenaran iman lain yang setia. ${ }^{4}$

Di tengah keberagaman itu, setiap pemeluk agama ditantang untuk tetap setia pada tradisi agamanya sendiri sekaligus untuk terbuka pada orang yang beragama lain. Dengan kata lain, teologi komparatif membuka kemungkinan bagi tumbuhnya sebuah keterbukaan untuk memahami tradisi keagamaan lain sembari tetap meyakini dan memperdalam tradisi keagamaan sendiri. Inilah pendekatan baru yang dipakai dalam teologi komparatif, di mana kita dapat belajar tentang (about) dan dari (from) tradisi agama-agama lain dan memungkinkan kita mengalami transformasi spiritual lewat perjumpaan dengan tradisi-tradisi agama ini. ${ }^{5}$

Sebagai sebuah model teologi, teologi komparatif ini ditandai oleh komitmennya untuk mempelajari tradisi-tradisi agama lain secara mendetail. Kekhasan teologi kompa-ratif terletak pada dimensi intelectum-nya yang didapatkan melalui perjumpaan-perjumpaan intensif dengan tradisi-tradisi agama lain. F.X. Clooney menyebutnya sebagai teologi yang secara mendasar ber-ubah oleh perhatiannya yang terinci terhadap detail-detail dari tradisi teologis dan keagamaan yang beragam; suatu teologi yang direkonstruksi hanya setelah praktek perban-dingan. ${ }^{6}$ Sementara itu James L. Fredericks mendefinisikan teologi komparatif ini sebagai usaha untuk memahami arti iman Kristiani dalam terang berbagai tradisi agama lain. Menurutnya, tujuan utama dari teologi komparatif adalah untuk memperoleh satu pemahaman agama Kristiani yang lebih baik. ${ }^{7}$

Berikut ini beberapa hal yang bisa dijadikan acuan dalam berteologi komparatif. 8 Pertama, teologi komparatif merupakan sebuah proses dialektis. Perbandingan dimulai dengan studi kritis atas agama lain, yang bisa dilakukan dengan membaca sejum-lah teks klasik, atau juga dengan melakukan dialog personal dengan praktisi dari agama lain, atau secara lebih optimal dengan melakukan kedua hal tersebut. ${ }^{9}$

Senada dengan hal ini, Clooney menyatakan bahwa refleksi teologis dalam teologi komparatif ini bisa dilakukan dalam berbagai konteks dan cara. Misalnya, dengan melihat bagaimana kebiasaan doa atau liturgi masing-masing agama, atau pun mendalami bagaimana musik atau seni lainnya. Bahkan dapat juga diangkat dari analisa sosial tentang bagaimana masingmasing agama mengangkat dan mengajarkan tentang solida-ritas terhadap mereka yang tertindas, atau juga bisa dilakukan berdasarkan pada sebuah pembacaan kritis terhadap ajaran-ajaran otoritas dari sebagian tradisi. ${ }^{10}$ Secara singkat dapat dikatakan bahwa refleksi teologis dalam teologi komparatif ini ditarik dengan cara memperbandingkan teks-teks agama dan atau juga dari praktek-praktek ritual yang ada melalui sebuah proses dialektis. Proses dialektis ini akan menghasilkan sebuah korelasi kritis dalam usaha perbandingan, baik segi positif maupun negatif. Bahkan kadang-kadang bisa juga menghasilkan perbedaan-perbedaan maupun persamaanpersamaan.

Kedua, dalam teologi komparatif perlu digarisbawahi bahwa berpikir secara interreligius merupakan sebuah aspek intrinsik dari usaha berteologi komparatif ini, bukan hanya sebuah refleksi tambahan dalam sistematikanya. Berteologi komparatif berarti bahwa korelasi doktrin-doktrin Kristiani dan praktek-praktek dengan tradisi agama lain ditempatkan pada pusat dari usaha pencarian (quaerens) teologi Kristiani itu sendiri. ${ }^{11}$ Clooney menggarisbawahi bahwa melalui teologi komparatif, seseorang memasuki sebuah jalan khusus untuk mempelajari tra-disi keagamaannya dari tradisi keagamaan lain. Ia menggambarkan bagaimana hendak-nya seorang teolog komparatif melakukan penelitiannya: duduk di belakang meja, mengambil sebuah teks dari agama lain, mengeluarkan kamus, dan membaca teks tersebut. ${ }^{12}$

Ketiga, masalah interpretasi yang muncul dari perbandingan tidak dapat dibatasi pada pertanyaan-pertanyaan soteriologis yang cenderung mendominasi teo- 
logi agama-agama. Teologi komparatif melingkupi setiap aspek, baik doktrin maupun kebiasaan/ praktek. Maka mempelajari teologi secara komparatif berarti dengan teliti menginter-pretasikan teksteks, doktrin-doktrin dan kebiasaankebiasaan dalam keseluruhannya.

Keempat, teologi komparatif mendasarkan diri pada percobaan-percobaan secara terbatas dalam usaha perbandingannya tentang tradisi agama lain daripada mempelajari secara umum. Clooney menyatakan:

Semakin spesifik suatu perbandingan, semakin baik; semakin khusus upaya seorang Kristen untuk memahami suatu teks atau praktek non-Kristiani, semakin baik; semakin banyak kita hadir untuk mempelajari suatu hal yang khusus dan gagasan yang sebelumnya merupakan "yang lain" bagi kita, semakin baik; dan semakin banyak kita menulis dari dalam bidang pengetahuan ini, dan tidak hanya itu saja, semakin baik. ${ }^{13}$

Kekhasan dari teologi komparatif dibandingkan dengan metode teologi lainnya terletak pada sifatnya yang "konstruktif". Perbedaan itu di antaranya nampak dalam kekhasan sumber dan metodenya, pendasar-annya terdiri atas lebih dari satu tradisi agama (meskipun si pembaca tetap berakar kuat pada satu tradisi tertentu), dan refleksi yang dibangun atas dasar tersebut, bukan hanya pada tema-tema atau pun metode yang sudah ada sebelumnya. ${ }^{14}$ Maka bisa dikata-kan bahwa teologi komparatif bersifat dina-mis dan cair karena tidak terikat oleh metode yang kaku dengan hasil yang sudah bisa diramalkan sebelumnya.

Bagus Laksana memberikan analogi menarik untuk menggambarkan bagaimana teologi komparatif ini dipraktekkan. Ia menganalogikan proses berteologi komparatif ini sebagai sebuah peziarahan yang pada gilirannya menentukan identitas seorang teolog komparatif. Ia memakai tiga kategori yang merupakan elemen penting yakni: identitas (identity), imajinasi (imagination), dan hospitalitas (hospitality). Melalui gambaran peziarah, ia menekankan bagaimana teologi komparatif itu meru- pakan sebuah proses untuk mengenal lebih dalam identitas diri di hadapan Allah dan tradisi agama lain. Ketika berhadapan dengan realitas yang lain itulah identitas diri sendiri justru semakin dibangun.

Dalam teologi komparatif, imajinasi juga mempunyai peran penting. Sebagaimana dalam peziarahan yang nyata, di mana perjumpaan seorang peziarah dengan Allah dan yang lain dimediasi oleh sejumlah kesan-kesan tertentu, perjalanan teologi komparatif pada tradisi agama lain juga menghasilkan aneka kesan. Inilah salah satu segi penting dalam teologi komparatif, yang mencoba menemukan berbagai cara untuk menggam-barkan kembali tradisi keagamaan dengan lebih jelas, dan dengan demikian semakin diperkaya oleh perjumpaannya dengan yang lain.

Ia juga menggarisbawahi peran penting hospitalitas dalam berteologi komparatif. Hospitalitas di sini dimaksudkan sebagai keterbukaan menerima dan diterima oleh yang lain. Teologi komparatif diharapkan terbuka pada yang lain dengan menempatkan dirinya dalam pergaulan di mana dirinya digambarkan kembali dalam kehadiran yang lain itu. Teologi komparatif juga diharapkan untuk terbuka pada yang lain, tidak hanya dengan menerima kehadiran yang lain akan tetapi juga mengulurkan tangan untuk mencapai yang lain.

Hasil apa yang bisa diharapkan dari usaha teologi komparatif ini? Bagus Laksana menegaskan bahwa seorang teolog kompa-ratif itu bagaikan seorang peziarah yang berani mengambil resiko untuk berlelah-lelah, kotor dan terlihat seperti pengembara, dan kemudian ia mendapatkan buah yang bermakna dan mentransformasi hidupnya dari perjalanan yang ia nikmati itu. Ia menyatakan bahwa setelah praktek perban-dingan itu, kekristenan akan dengan jelas tetap sebagai kekristenan, dan Islam tetap tinggal sebagai Islam, dan sebagainya, akan tetapi masingmasing mempunyai pengertian yang berbeda setelah praktek perbandingan itu karena masing-masing telah menjadi bagian dari identitas dari yang lain dalam cara yang berbeda, baik yang kelihatan maupun 
yang tidak kelihatan, baik yang dinyatakan dalam kata-kata maupun tidak. ${ }^{15}$

\section{AL-QUR'AN DALAM KEHIDUPAN UMAT MUSLIM ${ }^{16}$}

Menurut penulis, Al-Qur'an mempunyai tempat sentral dalam kehidupan umat Muslim. Sebagai Wahyu Ilahi, Al-Qur'an diturunkan Allah melalui perantaraan Malai-kat Jibril kepada Nabi Muhammad secara berangsur-angsur antara tahun 610 M sampai 632 M. Sementara sebagai mushaf atau kitab, proses peredaksian Wahyu Ilahi itu mengalami proses rumit dan panjang hingga diperoleh kitab seperti saat ini.

Secara singkat, berikut ini beberapa hal yang menunjukkan bagaimana Al-Qur'an mempunyai tempat penting dalam kehidupan umat Muslim. Penulis akan melihatnya secara singkat, khususnya dilihat dari ketiga dimensi yang sudah penulis sebutkan pada bagian sebelumnya.

\section{Dimensi Ummah}

Dari dimensi ini, penulis melihat bagaimana kaitan erat antara pewahyuan Al-Qur'an dengan lahirnya agama Islam. AlQur'an sendiri merupakan sumber utama ajaran Islam. Penulis berpendapat bahwa dengan adanya pewahyuan ini pada akhirnya membentuk suatu komunitas religius baru yakni agama Islam. Sebagai sebuah komu-nitas religius, Islam dipahami sebagai agama yang diwahyukan kepada Nabi Muhammad. Secara eksplisit, agama Islam ini disebutkan dalam wahyu terakhir yang diterima Nabi Muhammad sebagai agama yang diridhai Allah. "Pada hari ini telah Kusempurnakan untuk kamu agamamu, dan telah Ku-cukupkan kepadamu nikmat-Ku, dan telah Ku-ridhai Islam itu jadi agama bagimu" (QS 5:3).

\section{Dimensi Teologis}

Dari dimensi teologis ini, terdapat dua hal yang bisa dilihat sebagai alasan mendasar bagaimana umat Muslim menempatkan Al-Qur'an sebagai pusat hidup mereka. Pertama, umat Muslim percaya bahwa Al-Qur'an adalah Sabda Allah (kalam Allah) yang diwahyukan kepada
Nabi Muhammad melalui perantaraan malaikat Jibril. Sebagai Sabda Allah, esensi Al-Qur'an bersifat kekal dan tak tercipta. Sementara ungkapan atau wujudnya (dalam rupa bahasa, kata-kata) merupakan ciptaan dan tidak kekal, yang dalam hal ini, Sabda Allah itu diwahyukan dalam bahasa Arab (QS 12:2). ${ }^{17}$ Dalam hal ini, umat Muslim percaya bahwa dalam dan melalui Al-Qur'an itulah Allah yang bersabda, menuntun dan membimbing hidup mereka sendiri.

Kedua, umat Muslim percaya bahwa AlQur'an merupakan kitab yang terjaga kemurniannya. Meskipun wahyu Ilahi itu telah ditulis dan dikumpulkan dalam mushaf berbahasa Arab, umat Muslim meyakini bahwa kemurnian dan keaslian Al-Qur'an sebagai Sabda Allah itu tetap terjaga. Setidaknya ada dua alasan yang mendasari keyakinan itu: 1) ketidakmampuan baca tulis (ummi) Nabi Muhammad dan 2) penggunaan bahasa Arab secara umum dan turun-temurun.

Ketidakmampuan baca-tulis (ummi) Nabi Muhammad ini dianggap sebagai salah satu bukti bahwa Al-Qur'an tetap terjaga kemurnian dan keasliannya. Oleh karena Nabi Muhammad tidak bisa membaca atau menulis menggambarkan bahwa Sabda Allah itu tidak ditambah atau dikurangi sama sekali oleh nabi. Dengan demikian dapat dikatakan bahwa Nabi Muhammad bersifat pasif dan hanya bertindak sebagai penerima saja. ${ }^{18}$

Demikian juga dengan penggunaan bahasa Arab sebagai bahasa Al-Qur'an diyakini sebagai bukti bahwa isi Sabda Allah itu tetap seperti sejak awal pertamakali diwahyukan. Al-Qur'an sendiri menyatakan: "Sesungguhnya Kami menurunkannya berupa Al-Qur'an dengan berbahasa Arab, agar kamu memahaminya" (QS 12:2). Bagi umat Muslim, bahasa Arab merupakan 'bahasa suci' karena menjadi bagian integral pewahyuan. ${ }^{19}$ Meskipun saat ini sudah ada bermacam terjemahan Al-Qur'an, namun hal itu pertama-tama dimaksudkan agar umat yang non-bahasa Arab bisa memahami makna yang terkandung di dalamnya. Al-Qur'an bahasa Arab juga tetap 
dipertahankan penggunaannya dalam setiap ritual doa agama Islam.

\section{Dimensi Kerohanian}

Umat Muslim percaya bahwa tujuan utama diturunkannya Al-Qur'an adalah untuk memberikan bimbingan atau petunjuk (hidayah) bagi seluruh umat manusia (hudan li al-nas) menuju jalan kebahagiaan di dunia dan akhirat. Mahmoud Ayoub menyatakan demikian: "Al-Qur'an telah memainkan dua peran yang berbeda namun berkesinam-bungan dalam kehidupan umat Muslim. Ia adalah pedoman sepanjang jalan kehidupan yang meletihkan ini dan ke depan, suatu sumber berkat dan kehormatan bagi pem-bawanya (para penganut) di dunia ini dan pengantara mereka kepada Allah pada hari pengadilan." ${ }^{20}$ Dari pernyataan Ayoub tersebut bisa dikatakan bahwa bentuk bimbingan atau petunjuk yang ada dalam Al-Qur'an tidak lain adalah hal-hal yang menyangkut tentang keimanan, akhlak (moral), akidah (ideologi), ibadah, dll.

Sebagai bimbingan, Al-Qur'an juga menjadi pusat kehidupan rohani umat Muslim. Thomas Michel, seorang orientalis melihat bahwa Al-Qur'an merupakan pusat hidup spiritual atau kerohanian umat Muslim. Ia menyatakan demikian:

\begin{abstract}
"Spiritualitas agama Islam merupakan sebuah spiritualitas yang berpusat pada Al-Qur'an. Membaca, mendaraskan, mendengarkan, mempelajari dan merefleksikan Al-Qur'an merupakan sebuah bagian penting dari kehidupan devosional umat Muslim. Sebagaimana mereka percaya bahwa Al-Qur'an merupakan sabda Allah yang tertulis, perkataan Allah sendiri, maka perjumpaan mereka dengan Al-Qur'an merupakan perjumpaan dengan Allah yang mewahyukan diri, mengajar dan memben-tuk mereka yang percaya dalam kesucian." ${ }^{21}$
\end{abstract}

Menggarisbawahi kembali apa yang dikatakan Thomas Michel tersebut, saya kagum dengan upaya umat Muslim memberikan penghargaan luar biasa terhadap Al-Qur'an, baik sebagai mushaf maupun sebagai Sabda Allah. Misalnya, ada aturan bahwa mereka yang boleh menyentuh mushaf Al-Qur'an hanyalah mereka yang disucikan saja. "Sesungguhnya Al-Qur'an ini adalah bacaan yang sangat mulia, pada kitab yang terpelihara (lauhul mahfuzh), tidak menyen-tuhnya kecuali orang-orang yang disucikan. Diturunkan dari Rabbil "alamiin (Tuhan Semesta Alam)" (QS 56:77-80).

Sejumlah praktek juga memperlihatkan bagaimana umat Muslim berusaha menjadikan Al-Qur'an sebagai bagian hidup mereka. Bagi mereka, membaca dan mende-ngarkan bacaan Al-Qur'an merupakan sebuah ibadah dan amal yang mendatangkan pahala atau rahmat (lih. QS 7:204). Seyyed Hossein Nasr menyatakan bahwa Al-Qur'an berisikan sebuah kualitas yang merupakan "sebuah daya ilahi" dalam arti metafisis dan bukan dalam arti literal. Rumusan dalam Al-Qur'an, karena berasal dari Allah, mempunyai daya kekuatan yang tak bisa kita identifikasi secara rasional. Daya ilahi itulah yang disebut sebagai barakah (berkat). Praktek membaca dan mengingat Al-Qur'an dalam hati, mendaraskannya dari hari ke hari, menjadi indikasi bahwa bagi umat Muslim Al-Qur'an merupakan "makanan bagi jiwa-jiwa manusia." 22

\section{EKARISTI DALAM KEHIDUPAN UMAT KRISTIANI}

Berkaitan dengan peran dan tempat Ekaristi dalam kehidupan umat Kristiani, Konsili Vatikan II memberi penegasan bahwa Ekaristi merupakan sumber dan puncak kehidupannya (LG 11). Pernyataan tersebut memperlihatkan betapa pentingnya Ekaristi dalam hidup Gereja. Bahkan dalam artikel yang sama ditegaskan juga bahwa dengan ikut serta dalam kurban Ekaristi itu "mereka mempersembahkan Anak Domba Ilahi dan diri sendiri bersama dengan-Nya kepada Allah... Kemudian, sesudah memperoleh kekuatan dari Tubuh Kristus dalam perja-muan suci, mereka secara konkret menam-pilkan kesatuan Umat Allah, yang oleh sakra-men mahaluhur itu dilambangkan dengan tepat dan diwujudkan secara mengagumkan" (LG 11).

Bagian berikut ini akan memperlihatkan bagaimana peran dan tempat Ekaristi da- 
lam kehidupan umat Kristiani, khususnya dilihat dari dimensi ekklesiologis, teologis dan spiritualitas.

\section{Dimensi Ekklesiologis}

Pembahasan tentang dimensi ekklesiologis Ekaristi memperlihatkan hubungan erat dan tak terpisahkan antara Ekaristi dan Gereja. Ekaristi menjadi landasan dasar keberadaan Gereja sebagai persekutuan umat Allah (communio). Kesatuan umat Allah itu juga dilambangkan secara nyata dalam Ekaristi. Dan secara singkat dapat dikatakan bahwa Ekaristi dan Gereja memiliki hubungan yang saling membangun.

De Lubac menunjukkan betapa eratnya kaitan antara Gereja dan Ekaristi dengan mengatakan demikian: "Gereja dan Ekaristi dibentuk oleh satu sama lain dari hari ke hari: gagasan mengenai Gereja dan Ekaristi harus menjadi bagian satu sama lain dan masing-masing diberikan secara lebih mendalam oleh yang lain. Dengan makanan dan darah dari Tubuh Tuhan, biarlah semua persekutuan terikat bersama!"23 Dalam pandangan de Lubac tersebut, antara Gereja dan Ekaristi terletak hubungan yang sedemikian erat di mana keduanya saling membentuk dan menjadi bagian satu sama lain.

Secara khusus diperlihatkan juga bagaimana unsur unitif dari Ekaristi sendiri, yakni melalui Tubuh dan Darah Tuhan sendiri semua orang dipersatukan dalam ikatan yang sama. Dalam hal ini de Lubac juga menyatakan bahwa realisme Ekaristi dan Ekklesial (Gerejawi) juga merupakan dua realisme yang saling mendukung satu sama lain. Menurutnya, keduanya saling menjamin di mana realisme Ekklesial (Gerejawi) men-jaga keberadaan realisme Ekaristi dan juga sebaliknya.

Gerardo J. Bekes OSB menyatakan bahwa "pada saat Gereja merayakan Ekaristi, Ekaristi itulah yang membangun Gereja. Memang, perayaan Ekaristi menghadirkan secara sakramental misteri keselamatan, dan kehadirannya inilah yang menjadikan komunitas ekklesial sebagai persekutuan ilahi dan manusiawi: ilahi, bersama Allah melalui Yesus Kristus dalam
Roh Kudus; dan manusiawi, bersama saudara-saudari kita yang ikut-serta dalam misteri itu." 24

Menurut penulis, dimensi ekklesiologis dari Ekaristi dengan jelas hendak menyatakan bahwa Ekaristi sungguh membangun Gereja pada saat Gereja merayakan Ekaristi. Dalam hal ini, perayaan Ekaristi menghadirkan misteri keselamatan secara sakramental. Kehadiran dari misteri keselamatan itulah yang membentuk komunitas Gerejawi sebagai sebuah persekutuan yang Ilahi (dengan Bapa melalui Kristus dalam Roh Kudus) dan manusia (dengan umat yang ambil bagian dalam misteri itu).

\section{Dimensi Teologis}

Dilihat dari segi teologis, Ekaristi merupakan sakramen di mana Kristus sendiri hadir secara penuh dan nyata (realis praesentia) dengan seluruh misteri kesela-matan-Nya. Berkaitan dengan topik pem-bahasan tentang Al-Qur'an sebagai Sabda Allah, penulis merumuskan paham tentang realis praesentia itu demikian: Yesus Kristus, Sang Sabda menjadi Manusia, hadir secara penuh dan nyata dalam Ekaristi. Hal ini untuk menunjukkan bagaimana Ekaristi itu dialami dan dihayati oleh Gereja sebagai sakramen kehadiran Yesus Kristus, Sang Sabda itu, dalam kehidupan Gereja saat ini.

Terkait dengan peristiwa pewahyuan Yesus Kristus, Ekaristi menghadirkan kembali dan merayakan secara terus menerus seluruh peristiwa keselamatan Allah itu (lih. SC 6). Bagaimana peristiwa itu dihadirkan kembali? Para Bapa Konsili Vatikan II dalam SC 47 menegaskannya demikian:

Pada perjamuan terakhir, pada malam Ia diserahkan, Penyelamat kita mengadakan Korban Ekaristi Tubuh dan Darah-Nya. Dengan demikian Ia mengabadikan Korban Salib untuk selamanya, dan mempercayakan kepada Gereja Mempelai-Nya yang terkasih kenangan Wafat dan Kebangkitan-Nya: sakramen cintakasih, lambang kesa-tuan, ikatan cintakasih, perjamuan Paskah. Dalam perjamuan itu Kristus disambut, jiwa dipenuhi rahmat, dan kita dikurniai jaminan kemuliaan yang akan datang. 
Artikel tersebut memperlihatkan bagaimana Ekaristi menghadirkan kembali misteri dan karya keselamatan Allah. Nampak ada dua penekanan tentang makna Ekaristi, yakni pengabadian (perpetuare) Korban Salib dan kenangan (memoriale) Wafat dan Kebang-kitan Yesus Kristus. ${ }^{25}$

Ekaristi sebagai pengabadian Korban Salib berarti bahwa dalam Ekaristi itu kurban salib Kristus dihadirkan kembali secara nyata. Tindakan pengurbanan ini dinampak-kan pada saat konsekrasi roti dan anggur menjadi Tubuh dan Darah Kristus, yang dikenal dengan transubstantiatio. Dalam peristiwa inilah diakui bahwa Tubuh Kristus sendiri dipersembahkan bagi hidup dunia dan Darah-Nya ditumpahkan bagi semua orang demi pengampunan dosa. Melalui imam pemimpin, di mana mereka mempu-nyai kuasa, kata-kata dan tindakan Kristus diulangi dan dihadirkan kembali.

Sementara itu, pemahaman tentang Ekaristi sebagai kenangan atas wafat dan kebangkitan Kristus perlu dikaitkan dengan paham mengenai "sakramen". Agustinus membedakan "sakramen" dalam dua pengertian yakni sacramentum tantum (tanda sakramen) dan res sacramenti (isi sakramen). Dalam Ekaristi, yang menjadi tanda sakramen atau tanda suci (signum sacrum) adalah roti dan anggur yang dikonsekrasikan. Sementara yang menjadi isi sakramen adalah kehadiran Kristus sendiri dalam seluruh misteri penyelamatan-Nya. Di sinilah Ekaristi dipahami sebagai kenangan atas wafat dan kebangkitan Kristus. Legitimasi atas hal ini terdapat pada kata-kata Yesus saat perjamuan terakhir: "... perbuatlah ini menjadi peringatan akan Aku” (Luk 22:19).

\section{Dimensi Spiritualitas}

Dari dimensi spiritualitas dipahami bahwa Ekaristi merupakan sumber daya kehidupan rohani umat beriman Kristiani. Daya rohani itu tidak hanya mempengaruhi kehidupan pribadi umat beriman (ke dalam), melainkan juga menjadi pendorong umat beriman untuk mewujudkannya di tengah dunia (ke luar). Kesadaran bahwa Ekaristi merupakan sumber daya kehidupan beriman nampak dalam upaya umat beriman Kristiani ikut serta dalam setiap perayaan Ekaristi dan sejumlah praktek devosi kepada Sakramen Mahakudus.

Tempat dan peran sentral Ekaristi pertama-tama dilihat dari daya guna Ekaristi itu sendiri yang "bagaikan dari sumber, mengalirlah rahmat kepada kita, dan dengan hasil guna yang amat besar diperoleh pengudusan manusia dan pemuliaan Allah dalam Kristus, tujuan semua karya Gereja lainnya" (SC 10). Dengan merayakan Ekaristi, umat beriman Kristiani berusaha menimba rahmat keselamatan yang semata-mata berasal dari Allah. Dan di saat yang sama pula, Ekaristi menjadi saat di mana umat Kristiani mempersembahkan dirinya secara bebas kepada Allah melalui Kristus, Sang Imam Agung, oleh kekuatan Roh Kudus. Di dalam komuni, persatuan mesra antara Allah dan manusia yang terwujud melalui pemberian diri Allah kepada manusia dan tanggapan penuh kepercayaan manusia kepada Allah sungguh nampak nyata.

\section{REFLEKSI KOMPARATIF ATAS AL- QUR'AN DAN EKARISTI}

Pada bagian ini penulis hendak melakukan refleksi komparatif atas $\mathrm{Al}$ Qur'an dan Ekaristi. Bagian ini juga merupakan upaya untuk membaca kembali tradisi dan ajaran Gereja Katolik tentang Ekaristi setelah penulis mendalami tradisi dan ajaran Islam tentang Al-Qur'an. Diharapkan agar upaya untuk merefleksikan Ekaristi dengan diterangi oleh pemahaman tentang Al-Qur'an ini akan semakin memperkaya nilai-nilai iman yang penulis hayati, khususnya mengenai Ekaristi.

Pembahasan akan mencakup tiga bagian besar yakni: pertama, melihat aneka persamaan konseptual antara Al-Qur'an dan Ekaristi, kedua melihat aneka perbedaan antara Al-Qur'an dan Ekaristi, dan ketiga membaca kembali Ekaristi setelah menda-lami ajaran Islam tentang AlQur'an. 


\section{Persamaan Konseptual Al-Qur'an dan Ekaristi}

Perbandingan antara peran dan tempat Al-Qur'an dan Ekaristi dalam hidup beriman umat di kedua agama memperlihatkan sejumlah persamaan konseptual, antara lain:

Pertama, baik Al-Qur'an maupun Ekaristi berkaitan erat dengan komunitas beriman. Baik agama Islam maupun Katolik mempunyai hubungan erat satu sama lain dengan Al-Qur'an dan Ekaristi. Pewahyuan Al-Qur'an pada akhirnya membentuk satu komunitas religius yang baru. Dengan kata lain, lahirnya agama Islam didasari oleh pewahyuan Al-Qur'an yang diterima oleh Nabi Muhammad. Al-Qur'an ini pula yang menjadi sumber utama ajaran agama serta bimbingan bagi umat Muslim.

Demikian juga dengan Ekaristi merupakan landasan dasar keberadaan Gereja. Hubungan Ekaristi dan Gereja terjalin begitu erat: "Ekaristi membangun Gereja, Gereja membangun Ekaristi." Di satu sisi dipahami bahwa Ekaristi ada oleh karena dirayakan Gereja sebagai persekutuan umat Allah. Di sisi lain dipahami bahwa persekutuan (communio) Gereja sungguh nampak di dalam Ekaristi. Maka jati diri Gereja sebagai Tubuh Mistik Kristus mendapat perwujudan nyata dalam Ekaristi itu sendiri.

Kedua, Al-Qur'an maupun Ekaristi merupakan sebuah warisan tradisi iman yang terus terpelihara. Dalam tradisi Islam, Sabda Allah yang terkompilasi dalam mushaf Al-Qur'an itu merupakan warisan iman yang terus terpelihara. Hal yang sama dapat dilihat dalam Ekaristi, yang merupakan warisan iman yang ditinggalkan Yesus Kristus. Ekaristi sendiri diberikan sebagai kenangan akan karya keselamatan Allah dalam diri Yesus Kristus.

Penggunaan roti dan anggur dalam Ekaristi juga memperlihatkan kesamaan dengan penggunaan bahasa Arab bagi AlQur'an. Bagi agama Islam, penggunaan bahasa Arab sebagai "bahasa pewahyuan" juga tetap dipertahankan hingga kini, untuk memperlihatkan bagaimana Wahyu AlQur'an itu tetap terpelihara kesucian dan kemurniannya. Sementara penggunaan roti dan anggur dalam Ekaristi merupakan sebuah upaya mempertahankan kebiasaan suci yang berasal dari Yesus yang juga memakai roti dan anggur pada Perjamuan Terakhir, yang adalah Perayaan Paskah Yahudi.

Ketiga, secara teologis dapat dikatakan bahwa Al-Qur'an dan Ekaristi merupakan, dalam bahasa Kristiani, "sakramen" bagi umat beriman. Umat Muslim mengalami Allah yang membimbing umat-Nya melalui Sabda-Nya di dalam mushaf Al-Qur'an, sementara umat Katolik mengalami kehadiran Yesus Kristus dalam Ekaristi.

Bagi umat Muslim, melalui Al-Qur'an Allah terus menerus memberi bimbingan dan petunjuk kepada umat manusia. "Allah telah menurunkan perkataan yang paling baik (yaitu) Al-Qur'an yang serupa (mutu ayat-ayatnya) lagi berulang-ulang, gemetar karenanya kulit orang-orang yang takut kepada Tuhannya, kemudian menjadi tenang kulit dan hati mereka di waktu mengingat Allah. Itulah petunjuk Allah, dengan kitab itu Dia menunjuki siapa yang dikehendaki-Nya. Dan barangsiapa yang disesatkan Allah, niscaya tak ada baginya seorang pemim-pinpun" (QS 39:23). Kutipan ini menegaskan kembali tujuan diturunkannya Al-Qur'an yakni sebagai petunjuk bagi manusia. Dan kini petunjuk atau bimbingan Allah itu tetap dialami oleh umat manusia di dalam mushaf Al-Qur'an.

Sementara itu bagi umat Kristiani, kehadiran Allah juga dialami secara sakramental dalam Ekaristi. Bagi Gereja, Ekaristi merupakan sakramen (tanda) di mana Yesus Kristus hadir secara penuh dan nyata dengan seluruh misteri keselamatan-Nya. SC 47, sebagaimana telah disebutkan pada bagian sebelumnya, memberikan dua penekanan penting mengenai makna Ekaristi ini, yakni sebagai pengabadian korban salib dan kenangan wafat dan kebangkitan Yesus Kristus. Maka sebagai tanda kehadiran Allah, Ekaristi menyatakan dan menghadirkan kembali karya keselamatan Allah yang terjadi melalui korban salib, wafat dan kebangkitan Yesus Kristus.

Keempat, baik Al-Qur'an maupun Ekaristi mendapat tempat penting dan 
sentral bagi kedua agama, khususnya dalam kehidupan rohani. Secara singkat bisa dikatakan bahwa Al-Qur'an maupun Ekaristi merupakan sumber kekuatan spiritual atau rohani dalam kehidupan beriman umat di kedua agama. Al-Qur'an yang adalah Sabda Allah itu merupakan dasar kehidupan beriman umat Muslim, yang melalui Al-Qur'an umat Muslim memperoleh bimbingan dari Allah sendiri. Dengan membaca, mendaraskan, mendengarkan, mempelajari dan merefleksikan Al-Qur'an, umat Muslim berupaya untuk menimba rahmat Allah sendiri. "Dan Kami turunkan dari Al-Qur'an suatu yang menjadi penawar dan rahmat bagi orangorang yang beriman dan Al-Qur'an itu tidaklah menambah kepada orang-orang yang zalim selain kerugian" (QS 17:82).

Sementara itu bagi umat Kristiani, Ekaristi merupakan sumber daya hidup rohani yang pada akhirnya menjiwai seluruh kehidupan mereka. Umat Kristiani percaya bahwa dalam Ekaristi itu Allah Bapa dalam Yesus Kristus oleh Roh Kudus hadir secara nyata. Dilatarbelakangi oleh keyakinan bahwa dalam Ekaristi itu Kristus sungguh hadir (realis praesentia), maka umat Kristiani memberikan tempat yang istimewa terhadap sakramen Ekaristi ini.

Adanya keyakinan dan kesadaran akan pentingnya Ekaristi dalam kehidupan beriman, umat Kristiani berusaha untuk terusmenerus menimba rahmat keselamatan melalui Ekaristi. Misalnya, dengan ikut serta dalam perayaan Ekaristi harian atau pun hari Minggu, menyambut Tubuh dan Darah Kristus dalam komuni, maupun dalam praktek-praktek devosi Ekaristi yang ada. Bahkan saat ini banyak berkembang praktek misa keluarga atau lingkungan untuk menghaturkan ujub atau permohonan khusus yang dikaitkan dengan aneka peristiwa kehidupan mereka, misalnya syukur atas kelahiran, misa arwah, dll. Hal ini pun menjadi gambaran tentang kesadaran akan pentingnya Ekaristi dalam kehidupan seorang Kristiani.

\section{Sejumlah Perbedaan antara Al-Qur'an dan Ekaristi}

Meskipun ada sejumlah persamaan yang dapat dilihat antara Al-Qur'an dan Ekaristi, namun tak dipungkiri bahwa ada banyak hal yang membedakan keduanya. Adanya perbedaan-perbedaan ini tidak dimaksudkan untuk melihat siapa yang lebih baik, namun untuk menunjukkan bahwa keduanya memiliki pemahaman yang khas di dalam tradisi masing-masing.

Pertama, bagi Gereja Katolik, Ekaristi adalah satu dari tujuh sakramen Gereja. Ketujuh sakramen Gereja itu ialah Baptis, Krisma, Ekaristi, Tobat, Pengurapan Orang Sakit, Tahbisan, dan Perkawinan. Dalam hal ini, Sakramen Ekaristi mendapat tempat yang istimewa dibanding dengan sakramen-sakramen lainnya. Terlepas dari tempat Sakramen Ekaristi yang istimewa dibandingkan sakramen-sakramen lainnya, dalam hal ini kita bisa melihat bahwa Ekaristi bukan satu-satunya tanda dan sarana yang ditetapkan oleh Kristus untuk mendatangkan rahmat Allah. Hal ini berbeda dengan mushaf Al-Qur'an bagi umat Muslim. Bagi mereka, mushaf AlQur'an menjadi satu-satunya tanda di mana mereka berjumpa dengan Allah yang membimbing umat manusia dalam SabdaNya.

Kedua, sah-tidaknya Ekaristi tidak hanya ditentukan oleh ada-tidaknya roti dan anggur, tetapi juga seorang imam sebagai pemimpin perayaan Ekaristi. Hanya seorang imam-lah yang berhak memimpin perayaan Ekaristi. Seorang imam bertindak in persona Christi atau bertindak selaku pribadi Kristus (KHK Kan. 900§1). Maka bisa dikatakan bahwa tanpa imam, Ekaristi tidak bisa dirayakan. Hal ini berbeda dari pendarasan Al-Qur'an yang ada dalam praktek hidup umat Muslim. Bagi mereka, setiap orang dapat langsung membaca dan mendaraskan Al-Qur'an.

Dan ketiga, Ekaristi dan Al-Qur'an bisa dikatakan sebagai makanan jiwa yang diinternalisasikan ke dalam diri umat beriman. Terkait dengan cara penginternalisasian ini, ada cara yang berbeda di masing-masing agama. Bagi umat Kristiani, Ekaristi merupakan sesuatu yang disambut 
dan disantap sebagai makanan. Sementara bagi umat Muslim, Al-Qur'an merupakan sesuatu yang didengarkan atau pun didaraskan. Kedua cara ini menunjukkan perbedaan, meskipun pada akhirnya tujuannya sama yakni menjadikannya sebagai bagian dari hidup atau makanan rohani hidup mereka.

\section{Refleksi Komparatif Kristiani: Ekaristi, Kehadiran Sang Sabda menjadi Manusia}

Salah satu tujuan dari teologi komparatif adalah tumbuhnya sebuah keterbukaan untuk memahami tradisi keagamaan lain sembari tetap meyakini dan memperdalam tradisi keagamaan sendiri. Dengan kata lain, seorang komparativis berusaha belajar tentang dan dari tradisi agama lain untuk mendapatkan transformasi spiritual melalui perjumpaan itu. Pada bagian ini, penulis hendak merefleksikan beberapa hal sebagai sebuah afirmasi terhadap keyakinan tentang Ekaristi setelah mengalami perjumpaan dengan pemahaman Islam tentang Al-Qur'an.

\section{Ekaristi, Kehadiran Sang Sabda dalam Roti dan Anggur}

Hal pertama yang bisa dipetik dari bagaimana umat Muslim memahami AlQur'an adalah keyakinan bahwa dalam dan melalui Al-Qur'an, mereka mengalami Allah yang bersabda, menuntun dan membimbing mereka. Hal yang sama juga diyakini oleh Gereja, bahwa Yesus Kristus sungguh hadir secara nyata (realis praesentia) dalam Ekaristi, terutama dalam rupa roti dan anggur yang telah dikonsekrasi.

Selain itu, Gereja Katolik mempunyai tradisi menyimpan hosti suci dalam tabernakel karena percaya bahwa Kristus juga tetap hadir dalam hosti yang sudah diberkati itu. Praktek ini sempat menjadi persoalan dalam sejarah teologi, khususnya pada masa reformasi. Bagi Gereja Reformasi, realis praesentia itu hanya berlangsung sejauh roti itu disantap (in usu), sementara Gereja Katolik meyakini bahwa kehadiran Kristus itu bersifat tetap (extra usum), bahkan sesudah perayaan Ekaristi selesai.
Lepas dari bagaimana perdebatan itu, penulis belajar dari cara pandang umat Muslim tentang kehadiran Allah dalam mushaf Al-Qur'an. Penulis melihat bahwa di balik penghormatan (dalam arti sikap dan tatacara perilaku) terhadap mushaf AlQur'an, terdapat keyakinan mendalam dalam diri umat Muslim bahwa Sabda Allah itu hadir secara terus menerus, bukan hanya pada saat Al-Qur'an didaraskan. Keyakinan itu pada akhirnya mempengaruhi sikap dan tindakan mereka saat berjumpa dengan Al-Qur'an. Maka dalam hal ini, penulis dan umat Kristiani pun diundang pula untuk merefleksikan bagaimana sikap dan perilakunya dalam Ekaristi maupun saat hadir di hadapan Sakramen Mahakudus di mana Kristus senantiasa hadir.

Hal kedua penulis belajar dari bagaimana umat Muslim berupaya menjaga kesucian dan kemurnian Al-Qur'an. Bagi mereka, Al-Qur'an itu adalah sesuatu yang murni dan suci. Umat Kristiani pun meyakini bahwa Ekaristi merupakan tindakan yang sakral dan kudus. Maka sebagaimana umat Muslim sungguh berusaha untuk menyucikan diri sebelum menyentuh dan mendaraskan Al-Qur'an, penulis dan umat Kristiani lainnya pun semestinya berusaha sebaik mungkin mempersiapkan diri, baik hati maupun fisik untuk masuk dalam Ekaristi.

Dan yang ketiga adalah soal internalisasi dalam hidup. Dalam hal ini penulis diajak untuk semakin menjadikan Ekaristi sebagai bagian dari hidup. Hal ini didasari oleh kesadaran akan pentingnya Ekaristi dalam hidup beriman sebagai umat Kristiani. Sebagai sumber dan puncak kehidupan beriman Kristiani (lih. LG 11), Ekaristi menjadi saat penting di mana Allah hadir menjumpai, menyatukan, membimbing dan pada akhirnya menguatkan umatNya untuk melanjutkan karya keselamatan di tengah dunia.

Dari ketiga hal ini, penulis semakin memahami makna penting dari ajaran Gereja yang menyatakan bahwa Ekaristi adalah sumber dan puncak hidup Gereja (LG 11). Penulis memaknai Ekaristi sebagai sumber dan puncak hidup Gereja pertama- 
tama karena di dalam Ekaristi itulah Allah hadir menjumpai umat-Nya, menyatukan umat-Nya, membimbing umat-Nya dan pada akhirnya menguatkan umat-Nya untuk melanjutkan karya keselamatan di tengah dunia. Dan belajar dari umat Muslim, umat Kristiani mengalami kehadiran Yesus Kristus, Sang Sabda menjadi manusia dalam Ekaristi, sebagaimana umat Muslim mengalami Sabda Allah dalam mushaf Al-Qur'an.

\section{Spiritualitas Ekaristi yang Inkarnatif}

Ekaristi merupakan sebuah perayaan syukur Gereja atas karya keselamatan Allah melalui Yesus Kristus dalam Roh Kudus. Dalam perayaan Ekaristi itu, rasa syukur nampak jelas dalam aneka lagu yang dinyanyikan, doa-doa yang didaraskan, dan terlebih dalam kesatuan di antara seluruh jemaat yang hadir. Dan sebagai puncaknya, umat beriman menerima santapan rohani Tubuh dan Darah Kristus dalam komuni. Santapan rohani inilah yang menjadi bekal perjalanan hidup selanjutnya.

Ekaristi memang mewujudkan kesatuan Gereja sebagai anggota Tubuh Mistik Kristus. Setiap anggota bersatu dalam perayaan yang sama, tanpa memandang latar belakang sosial, ekonomi maupun usia. Maka bisa dikatakan bahwa Ekaristi dan Gereja merupakan satu kesatuan yang tak ter-pisahkan. Akan tetapi, apakah Ekaristi ini juga menjiwai seluruh hidup untuk bersatu dengan mereka yang berada di luar kesatuan Gereja? Bagaimana Ekaristi juga dapat merangkul mereka yang ada di luar kesatuan Gereja?

Merangkul mereka yang berada di luar kesatuan Gereja semestinya menjadi bagian penting dari Ekaristi. Hal ini tidak diartikan sebagai melibatkan orang-orang nonKristiani dalam perayaan Ekaristi, namun terlebih bagaimana Ekaristi itu sendiri mendorong umat Kristiani juga menyatukan seluruh dunia dalam satu kesatuan kasih. Dengan kata lain, Ekaristi mendorong agar semua orang turut ambil bagian dalam makanan yang sama yakni Tubuh dan Darah Kristus sendiri.

Pemahaman tentang Al-Qur'an memper-lihatkan bahwa Sabda Allah yang kekal itu diturunkan oleh Allah untuk membimbing manusia. Artinya bahwa Sabda Allah yang kekal itu kini dapat dijumpai oleh umat manusia dalam Al-Qur'an. Dalam bahasa Kristiani, Sabda Allah itu berinkarnasi sehingga dapat menyentuh dan membimbing manusia secara langsung. Pemahaman ini mendorong kita untuk memikirkan sebuah spiritualitas Ekaristi yang inkarnatif. Artinya, sebagai tanda kehadiran nyata Yesus Kristus, Ekaristi juga semestinya ber-inkarnasi ke dalam dunia.

Sebagaimana Yesus, Sang Sabda Allah itu berinkarnasi yakni meninggalkan surga mulia untuk masuk ke dalam hiruk pikuk kehidupan manusia, demikian juga Ekaristi juga perlu mendorong umat Kristiani untuk masuk sedalam-dalamnya ke dalam kehidupan dunia. Dengan demikian Sang Sabda Allah itu pun dapat dirasakan oleh umat manusia secara nyata. Dan kini umat Kristiani mengalami Yesus Sang Sabda Allah itu dalam rupa roti dan anggur Ekaristi yang mereka santap sebagai makanan rohani. Semangat inkarnatif yang sama juga harus dihidupi oleh umat Kristiani yang telah diteguhkan oleh Kristus sendiri melalui Ekaristi dalam kehidupan sehari-hari. Inilah spiritualitas Ekaristi yang inkarnatif.

Dengan mewujudkan spiritualitas Ekaris-ti yang inkarnatif inilah kesatuan Ekaristi akan menjadi lebih luas cakupannya. Ekaristi bukan hanya menyatukan mereka yang menjadi anggota Gereja, melainkan juga dapat merangkul mereka yang ada di luar kesatuan Gereja. Dengan demikian Ekaristi tidak hanya berhenti pada dimensi ekklesial, teologis, maupun spiritual saja, melainkan juga segi sosial yang nyata, di mana pada akhirnya semua orang bersama-sama mensyukuri rahmat Allah yang senantiasa membimbing dan menuntun manusia menuju keselamatan. Syukur inilah yang juga merupakan makna dasar dari Ekaristi.

\section{PENUTUP}

Sebagai refleksi akhir dari artikel ini, penulis hendak memberikan beberapa rangkuman setelah mempraktekkan teologi komparatif. Pertama-tama penulis hendak 
menggarisbawahi bahwa teologi komparatif menjadi sebuah metode teologi yang kontekstual bagi situasi pluralitas agama. Alasan mendasar dari keyakinan ini dilatarbelakangi oleh proses dan tujuan dari teologi komparatif sendiri. Proses teologi komparatif memerlukan adanya perjumpaan antara dua tradisi agama atau lebih. Sementara tujuannya adalah untuk belajar tentang dan dari agama lain. Melalui perjumpaan itulah akan memungkinkan terjadinya sebuah keterbukaan akan keberadaan agama lain.

Kedua obyek yang dipilih, yakni AlQur'an dan Ekaristi, dalam upaya memperdalam teologi komparatif ini hanyalah satu di antara sekian banyak obyek yang bisa dikaji dalam teologi komparatif. Dalam hal ini bisa dikatakan bahwa obyek kajian teologi komparatif tidak terbatas. Ada begitu banyak kajian yang bisa dipilih oleh praktikan untuk memperdalam teologi komparatif ini. Hal ini menjadi peluang bagi semakin berkem-bangnya teologi komparatif.

Keunggulan dari teologi komparatif dibandingkan dengan aneka metode teologi yang lain adalah adanya praktek perjumpaan dalam teologi komparatif. Teologi komparatif tidak menawarkan sebuah teori yang siap dihidangkan untuk dipakai, tapi merupakan sebuah praktek dan proses yang harus dilalui. Melalui praktek inilah "buah" dari teologi komparatif akan lebih mudah dirasakan dan didapatkan.

Dan akhirnya penulis berharap agar teologi komparatif akan semakin berkembang dan pada akhirnya memperkecil adanya klaim kebenaran yang seringkali memicu aneka konflik di tengah pluralitas iman. Bagaimanapun, disadari atau tidak, keberagaman iman dan agama ini tak jarang menimbulkan potensi konflik. Maka dari itu, teologi komparatif menjadi alternatif pilihan yang akan menjawab aneka tantangan dari keberagaman itu sendiri.

\section{Stepanus Sigit Pranoto}

Alumnus Magister Teologi Universitas Sanata Dharma Yogyakarta

Email :sspranoto86@gmail.com

\section{CATATAN AKHIR}

1 George Dardess, Do We Worship the Same God? Comparing the Bible and the Qur'an, (Bangalore India: St Paul Press, 2006), 33

2 Thomas Michel SJ, "The Idea of Holiness in Islam”, dalam Christian View of Islam, New York: Orbis Books, (2010): 220.

3 F.X. Clooney SJ, Comparative Theology: Deep Learning Across Religious Borders, (United Kingdom: Wiley Blackwell, 2010), 3

4 Yohanes Berchmans Prasetyantha MSF, The Incarnate Word of God: Christian and Islamic Doctrine on Revelation. A Study in Comparative Theology, (Roma: Facultas Theologiae Pontificia Universtas Gregoriana, 2005), 18.

5 A. Bagus Laksana, "Teologi Komparatif: Mengatasi Debat Pluralisme dan Inklusivisme", ProManuscripto (Yogyakarta: Seminar Teologi Komparatif, Fakultas Teologi Universitas Sanata Dharma, 2005): 1.

6 Francis X. Clooney SJ, "Comparative Theology: A Review of Recent Books (1989-1995)," Theological Studies 56 (1995), 522

7 Paul F. Knitter, Pengantar Teologi Agama-Agama, 242

8 Penulis mencoba merumuskan keempat acuan ini dari pemikiran James L. Frederick dan FX Clooney SJ.

9 James L. Fredericks, "Introduction" dalam F.X. Clooney SJ (Ed), The New Comparative Theology, $\mathrm{xi}$

10 F.X. Clooney SJ, Comparative Theology, 57

11 James L. Fredericks, "Introduction" dalam F.X. Clooney SJ (Ed), The New Comparative Theology, xii

12 F.X.Clooney SJ, "Comparative Theology - As Theology", 136

13 F.X. Clooney SJ (Ed), The New Comparative Theology, xii

14 Francis X. Clooney SJ, "Comparative Theology: A Review of Recent Books (1989-1995)," 522

15 A.Bagus Laksana, "Comparative Theology: Between Identity and Alterity" dalam F.X.Clooney SJ (Ed), The New Comparative Theology, 1-20

16 Istilah Al-Qur'an ini sebaiknya dibedakan antara bentuk/wujud lahiriah dan isinya. Sebagai bentuk, Al-Qur'an disebut sebagai mushaf atau kumpulan lembaran, atau kitab/buku. Sementara isinya menunjuk pada Wahyu Ilahi yang diturunkan Allah melalui malaikat Jibril kepada Nabi Muhammad. Memang keduanya saling terkait satu sama lain. Maka untuk membedakan pada saat mana Al-Qur'an disebut sebagai bentuk atau pun isinya, dalam artikel ini akan diberikan keterangan sesuai dengan yang dimaksudkan dalam konteks tulisan.

17 Lih. Harry Austryn Wolfson, The Philosophy of the Kalam, (Cambridge: Harvard University Press, 1976), 235-303.

18 Seyyed Hossein Nasr, Ideals and Realities of Islam, (London: George Allen \& Unwin Ltd., 1966), 42

19 Claude Gilliot, "Creation of a fixed text" dalam Jane Dammen McAuliffe (Ed.), The Cambridge 
Companion to the Qur'an, (New York: Cambridge University Press, 2006), 43.

20 Mahmoud M. Ayoub, The Qur'an and Its Interpreters (Vol I), (Albany: State University of New York Press, 1984), 7-8.

21 Thomas Michel SJ, "The Idea of Holiness in Islam" dalam Christian View of Islam, Orbis Books (2010): 220.

22 Seyyed Hossein Nasr, Ideals and Realities of Islam, (London: George Allen \& Unwin Ltd., 1966), 51-52.

23 Henri Cardinal de Lubac SJ, Corpus Mysticum: The Eucharist and the Church in the Middle Ages (Edisi Terj. Bahasa Inggris oleh Lancelot C. Sheppard), (New York: Mentor-Omega Book, 1964), 260.

24 Gerardo J. Bekes OSB, "Chapter 35 The Eucharist Makes the Church: The Ecclesial Dimension of the Sacrament" dalam Rene Latourelle (Ed), Vatican II. Assessment and Perspectives: twentyfive years after (1962-1987) (Vol II), New York:Paulist Press, (1989): 347.

25 Josef Andreas Jungmann, "Constitution on the Sacred Liturgy" dalam Herbert Vorgrimler (Ed), Commentary on the Documents of Vatican II (Vol. I), London: Burn\&Oates, (1967): 33.

\section{DAFTAR RUJUKAN:}

Al-Qaradawi, Sheikh Yusuf., How to Approach the Qur'an, Kairo: Al-Falah Foundation, 2001.

Amal, Taufik Adnan., Rekonstruksi Sejarah Al-Quran, Jakarta: Pustaka Alvabet, 2013.

as-Said, Labib., The Recited Koran: A History of the First Recorded Version, New Jersey: The Darwin Press, 1975

Ayoub, Mahmoud M., The Qur'an and Its Interpreters (Vol I), Albany: State University of New York Press, 1984.

Bekes OSB, Gerardo J., "Chapter 35 The Eucharist Makes the Church: The Ecclesial Dimension of the Sacrament" dalam Rene Latourelle (Ed), Vatican II. Assessment and Perspectives: twenty-five years after (1962-1987) (Vol II), Paulist Press, New York (1989).

Burton, J., The Collection of the Qur'an, Cambridge: Cambridge University Press, 1977.
Cheetham, dkk (Eds), D., , Interreligious Hermeneutics in Pluralistic Europe Between Texts and People, USA: Rodopi, 2011.

Clooney SJ, F.X., "Comparative Theo-logy: A Review of Recent Books (19891995)" dalam Theological Studies 56 (1995).

Comparative Theology: Deep Learning Across Religious Borders, United Kingdom: Wiley Blackwell, 2010.

The New Comparative Theology, New York:T\&T Clark, 2010

Dardess, G., Do We Worship the Same God? Comparing the Bible and the Qur'an, Bangalore India: St Paul Press, 2006.

Graham, William A., Beyond the Written Word: Oral Aspects of Scripture in the History of Religion, Cambridge: Cambridge University Press, 1987.

Jacobs, Dr.T., Konstitusi Dogmatis 'Dei Verbum' tentang Wahju Ilahi: Terdjemahan-Introduksi-Komentar, Yogyakarta: Kanisius, 1969.

"Refleksi Teologis tentang Ekaristi" dalam J.B. Banawiratma (Ed.), Baptis, Krisma, Ekaristi, Yogyakarta: Kanisius (1989).

Lubac, Henri de., Catholicism: A Study of Dogma in Relation to the Destiny of Mankind, (Edisi Terj. Bahasa Inggris oleh Lancelot C. Sheppard), New York, Mentor-Omega Book, 1964.

Corpus Mysticum: The Eucharist and the Church in the Middle Ages, (terj. Inggris oleh Gemma Simmonds CJ), Indiana: University of Notre Dame Press, 2006.

Kasper, Walter., Theology \& Church, New York: Crossroad, 1989

Sacrament of Unity: the Eucharist and the Church, New York: Herder\&Herder, 2004. 
Laksana, A. Bagus., "Teologi Komparatif: Mengatasi Debat Pluralisme dan Inklusivisme", Pro-Manuscripto Seminar Teologi Komparatif, Fakultas Teologi Universitas Sanata Dharma, Yogyakarta, 2005.

"Comparative Theology: Between Identity and Alterity" dalam F.X.Clooney SJ (Ed), The New Comparative Theology, New York: T\&T Clark, 2010.

Longhurst, C.E., "Eucharistic Spirit of Islam Parallels Between Islam and Christianity on the Eucharist", dalam Encounter N. 382-383, February-March 2013, Pontifico Istituto di Studi Arabi e d'Islamistica, Roma (2013).

Madjid, Dr. Nurcholish., Islam Doktrin dan Peradaban, Jakarta: Yayasan Wakaf Paramadina, 1992.

Mahmud, Moh. Natsir., , "Al-Qur'an di Mata Barat: Sebuah Studi Evaluatif" dalam Al-Hikmah: Jurnal Studi Islam, No. 12, Januari-Maret, Bandung: Yayasan Muthahhari, (1994).

Michel SJ, Th., "The Idea of Holiness in Islam" dalam Th. Michel SJ, Christian View of Islam, New York: Orbis Books, 2010.

Nasr, Seyyed Hossein, Ideals and Realities of Islam, London: George Allen \& Unwin Ltd, 1966.

Nelson, Kristina, The Art of Reciting the Qur'an, Austin: University of Texas Press, 1985.

Osborne OFM, Kenan B., Komunitas, Ekaristi, dan Spiritualitas (Edisi Terjemahan), Yogyakarta: Kanisius, 2008.

Powers, Joseph M., Eucharistic Theology, New York: The Seabury Press, 1967.
Prakosa, JB. Heru., "Kenabian dalam Tradisi Islam dan Rekam Jejak serta Penuturannya" dalam Orientasi Baru: Jurnal Filsafat dan Teologi, Vol. 22, No. 1, (April 2013).

Prasetyantha MSF, Y.B., The Incarnate Word of God: Christian and Islamic Doctrine on Revelation. A Study in Comparative Theology, Roma: Facultas Theologiae Pontificia Universtas Gregoriana, 2005.

Al-Qur'an Sebagai Sabda Allah, Studi Kristiani Mengenai Doktrin Islam tentang Pewahyuan, Yogyakarta: Amara Books, , 2010.

Qutb, Sayyid., Milestones, England: Maktabah Booksellers and Publishers, 2006.

Rahman, Fazlur., Tema Pokok Al-Qur'an, Bandung: Penerbit Pustaka, 1980.

Reinier Theodorus Maria Peters Johannes., God's Created Speech, Leiden: E.J. Brill, 1976.

Robinson, Neal., Discovering Qur'an: a Contemporary Approach to a Veiled Text (Second Edition), Great Britain: SCM Press, 2003.

Sands, Kristin Zahra., Sufi Commentaries on the Qur'an in Classical Islam, New York: Routledge, 2006.

Shihab, Dr.M.Quraish., "Membumikan" Al-Qur'an, Bandung: Penerbit Mizan, 1994.

Lentera Al-Qur'an: Kisah dan Hikmah Kehidupan, Bandung: Penerbit Mizan, 1994.

Wawasan Al-Qur'an: Tafsir Tematik atas Pelbagai Persoalan Umat, Bandung: Penerbit Mizan, 1996. 
Thanthawi, Dr Muhammad Sayyid., Ulumul Qur'an: Teori\&Metodologi (Ed. Terjemahan), Yogyakarta: IRCiSoD, 2013.

Tim Redaksi Pesantren, "MTQ, Riwayatmu Dulu" dalam Pesantren, No. 1/Vol. VIII/1991(1991).

Watt, W. Montgomery and Richard Bell, Introduction to the Qur'an, Edinburgh: Edinburgh University Press, 1970.
Whalen, Teresa., The Authentic Doctrine of the Eucharist, Kansas City: Sheed\&Ward, 1993.

Wolfson, Harry Austryn, The Philosophy of the Kalam, Cambridge: Harvard University Press, 1976. 